\title{
TH1 LYMPHOCYTES: CORRELATES OF PROTECTION OR MARKERS OF TUBERCULOSIS INFECTION ACTIVITY?
}

Lyadova IV $\otimes$, Panteleev AV, Nikitina IYu, Radaeva TV

Laboratory of Biotechnology, Central Tuberculosis Research Institute, Moscow

Development of new tuberculosis (TB) vaccines and host-oriented therapy requires understanding mechanisms mediating protective antituberculous immunity. Antigen-specific Th1 lymphocytes have long been considered as the main correlate of TB protection. However, recent data do not confirm this concept. This article discusses debatable issues concerning the role for Th1 lymphocytes in antituberculous immunity, as well as their use as correlates of protection in preclinical and clinical studies assessing the effectiveness of new candidate TB vaccines.

Keywords: tuberculosis, latent tuberculosis infection, Th1 lymphocytes, IFNY

Funding: the study is part of the Central Tuberculosis Research Institute's stream 0515-2015-0010, "Immunological methods of pulmonary tuberculosis diagnosing".

$\square$ Correspondence should be addressed: Irina V. Lyadova

Yauzskaya Alley 2, Moscow, 107564; ivlyadova@mail.ru

Received: 29.05.2018 Accepted: 25.07.2018

DOI: $10.24075 /$ brsmu.2018.036

\section{ЛИМФОЦИТЫ ТН1: КОРРЕЛЯТЫ ПРОТЕКЦИИ ИЛИ МАРКЕРЫ АКТИВНОСТИ ТУБЕРКУЛЕЗНОЙ ИНФЕКЦИИ?}

\author{
И. В. Лядова ${ }^{凶}$, А. В. Пантелеев, И. Ю. Никитина, Т. В. Радаева
}

Лаборатория биотехнологии, Центральный научно-исследовательский институт туберкулеза, Москва

\begin{abstract}
Создание новых противотуберкулезных вакцин и разработка методов патогенетической хозяин-ориентированной терапии туберкулеза требуют понимания механизмов, ответственных за протективный противотуберкулезный иммунитет. На протяжении долгого времени основным коррелятом протекции считались антиген-специфичные лимфоциты Th1. Однако со временем накопились сведения, не согласующиеся с этой концепцией. В статье обсуждаются спорные вопросы, касающиеся роли лимфоцитов Тh1 в противотуберкулезном иммунитете, и возможности их использования в качестве коррелятов протекции при проведении доклинических и клинических исследований эффективности разрабатываемых вакцинных препаратов.
\end{abstract}

Ключевые слова: туберкулез, латентная туберкулезная инфекция, лимфоциты Th1, IFNy

Финансирование: исследование выполнено в рамках темы НИР ФГБНУ «ЦНИИТ» 0515-2015-0010 «Иммунологические методы в диагностике туберкулеза легких».

$\triangle$ Для корреспонденции: Ирина Владимировна Лядова Яузская аллея, д. 2, г. Москва, 107564; ivlyadova@mail.ru

Статья получена: 29.05.2018 Статья принята к печати: 25.07.2018

DOI: 10.24075 /vrgmu.2018.036

In the Russian Federation, tuberculosis (TB) is on the decline [1]. However, despite the decreasing morbidity and mortality rates, the disease is still a serious threat, especially considering the spread of HIV infection and drug-resistant strains of Mycobacterium tuberculosis (Mtb). Other factors that contribute to TB spread are new immunity disrupting factors, such as commonization of transplantation, spread of autoimmune diseases and allergies, population ageing, insufficient physical activity. There are reasons to believe that they will play an increasingly important role. In this connection, host-oriented therapy aimed to optimize host immunity during TB disease and new TB vaccines able to prevent TB disease show promise. However their development requires understanding the mechanisms of antituberculous defense and knowing immunological correlates of protection. The latter is especially crucial for preclinical and clinical studies of new TB vaccines, as assessment of their effectiveness is challenging and largely based on the evaluation of vaccine immunogenicity. Unfortunately, exact mechanisms of TB protection are not fully clear, and TB protection correlates remain unidentified. Antigenspecific Th1 lymphocytes have long been considered as the main correlate of TB protection. However, recent data have not confirmed this concept. This article discusses debatable issues concerning the role for Th1 lymphocytes in antituberculosis immunity and their potential usage as TB correlate of protection.

Dependence of protective antituberculous immunity on Th1 lymphocytes response

Since the immunology of TB became a subject of research, protective antituberculous immunity has been attributed to $\mathrm{CD}^{+}$Th1 lymphocytes that activate macrophages for mycobacteria killing [2-7]. There are a large number of experiments and clinical studies supporting this concept. Indeed, CD4 T cell deficiency, either due to HIV infection or induced experimentally, increases TB risk in people and makes the disease severe in laboratory animals [8-12]. In mice that have IFN $\gamma$, TNF $\alpha$, IL12, iNOS or other genes involved in IFN $\gamma$ dependent response knocked out, infection with Mtb leads to severe conditions and rapid death [13-19]. Children with mutations in genes of $I L 12 / I F N \gamma$ axis (i.e., IFNGR1, IFNGR2, IL12B, IL12RB1, STAT1, IRF8, ISG15, NEMO, CYBB) are more 
susceptible to mycobacterial infections, including TB, and the diseases developed thereof typically take severe forms [20-29]. Cytokine anti-TNF therapy is another factor known to heighten the risk of TB development [30, 31]. In mice, antimycobacterial activity of macrophages depends on the production of active oxygen and nitrogen activated by type 1 cytokines IFN $\gamma$ and TNF $\alpha$ [32-37].

The data mentioned laid the foundation of the concept stating that Th1 lymphocytes are the main activators of macrophages and mediators of TB protection. However, in fact, the data summarized above indicate that deficiency in Th1 response leads to TB development, but this does not mean that TB always results from Th1 response deficiency. Moreover, a series of experimental studies and clinical observations of the recent years have challenged the existence of association between TB development and Th1/IFN $\gamma$ deficiency.

\section{Lack of correlation between the levels of Th1 responses and TB protection: experimental findings}

BCG-vaccinated mice infected with Mtb have shown no correlation between the level of BCG-induced protection and the level of IFN $\gamma$ synthesized by $\mathrm{CD}^{+}$lymphocytes [38, 39]. Several studies have reported that $\mathrm{CD}^{+}$lymphocytes, derived from IFN $\gamma^{-/-}$mice and differentiated in Th1-polarizing conditions, are capable of controlling the multiplication of $M$ tb in vitro [40] and in vivo when transferred adoptively [41, 42]. Thus, the lack of IFNy does not prevent sufficiently effective control over Mtb multiplication in mice.

In contrast to the control of Mtb multiplication, protection against pathological reactions in the lung tissue did require IFN $\gamma$. Nandi \& Behar [42] have adoptively transferred CD4 ${ }^{+}$ $\mathrm{IFN} \gamma^{-1-}$ lymphocytes to $\mathrm{RAG}^{-1}$ Mtb-infected mice. IFN $\gamma^{-1-}$ lymphocytes protected recipient mice against $M$ tb multiplication as effectively as lymphocytes derived from wild-type mice, however unlike the latter, IFN $\gamma^{-1-}$ lymphocytes did not protect mice from pathological reactions in their lungs and death. The authors linked protective activity of IFNy to its ability to decrease the induction of "pathological" Th17 population and neutrophilic infiltration, i.e., inflammation control. At the same time, Barber and coauthors have recently shown that excessively high production of IFN $\gamma$ can do damage and lead to death of Mtb-infected mice [43, 44].

Thus, recent studies have demonstrated that Th1/IFN $\gamma$ response can be more complex than plain activation of the macrophages' antimycobacterial properties, and that the state of protection is largely determined by the organism's ability to control inflammatory responses to the infection. Moreover, no correlation between the level of vaccine-induced Th1/IFNy response and protection against experimental tuberculosis infection was found.

\section{Th1/IFN $\gamma$ responses to mycobacteria in humans: contradictory data}

Despite the afore-mentioned fact that Mtb multiplication in mice can be controlled in the absence of T-cell derived IFN $\gamma$, the mainstay concept considers IFN $\gamma$ as the main part of the pathway "T cells - IFN - iNOS - active forms of nitrogen macrophage activation - suppression of Mtb growth". However this pathway does not seem to describe the processes ongoing in human macrophages: several studies reported that in human macrophages IFNy did not stimulate active nitrogen production and did not cause significant suppression of Mtb multiplication [33, 45, 46]. Interestingly, a recent study by Meyer and coauthors found no significant impact of IFNy pathway gene variants on tuberculosis susceptibility in a West African population (analysis included 20 genes in samples obtained from 23 TB patients and 46 healthy donors, and exon gene analysis of IFNGR1 in 1999 samples from TB patients and 2589 control samples) [47].

One of the most common approaches to analyze the contribution of various immune responses to TB protection in human beings implies comparing the responses in TB patients and TB contacts who did not develop disease. The results of such comparative studies are ambiguous. Some of them have reported smaller numbers of Mtb-specific Th1 lymphocytes and weaker IFN $\gamma$ production in TB patients, which is taken as an argument proving that these types of responses contribute to TB protection [48-52]. However, in other studies the amount of cells producing IFNy and the levels of IFNy and TNF $\alpha$ production in TB patients were higher than those seen in people with latent tuberculosis infection (LTBI) and healthy donors [53-55]. In our studies, the levels of antigen-stimulated IFN $\gamma$ production were higher in TB patients compared to TB contacts and individuals with LTBI; moreover, we have registered higher IFNy production in patients with active TB compared to patients with residual post-tuberculous lung tissue alterations [56]. We have also shown that the group of patients with recently diagnosed TB had greater percentages of IFN $\gamma$ and TNF $\alpha$ producing CD4+ lymphocytes than people with LTBI, TB contacts and healthy donors [57]. In contrast to patients with recently diagnosed TB, patients with chronic TB do exhibit signs of Th1 inhibition, but apparently this is a secondary process [58].

Another approach that allows investigating mechanisms of immune protection implies comparison of immunological parameters in TB patients with diverse TB severity. The approach is based on a thorough assessment of the severity of diverse TB manifestations in each patient included in the study. TB manifestations considered in our study included clinical TB forms (tuberculoma, infiltrative TB, focal TB, cavernous and fibrous-cavernous TB, disseminated TB); TB extent (evaluated based on the number of lung segments and lobes affected by the pathology); the degree of lung tissue destruction (i.e., number and size of foci of destruction); bacterial excretion (presence, level of); clinical severity of the disease (assessed by temperature and other clinical signs of intoxication). Correlation and cluster analyzes did not reveal significant associations between these TB manifestations and the levels of Th1 responses (i.e, the percentages and absolute numbers of CD4 lymphocytes producing IFN $\gamma, \mathrm{TNF} \alpha$, IL2, their various combinations, the level of antigen-induced IFN $\gamma$ production in the Quantiferon-TB gold in-tube test) $[56,57]$. Thus, it can be deduced that in most cases the intensity of Th1 response does not affect the post-infection development or non-development of the disease, and neither does it influence the course of TB disease. It seems that, provided there are no significant defects (like HIV-related deficiency of CD4 lymphocytes or mutations in IL12 / IFNy chain genes), the host organism is capable of mounting a Th1 response proportionate to the threat, and the quantitative characteristics of such response (which differ from person to person), do not have a significant effect on the outcome of the infection.

This conclusion is in line with the results of studies researching the relationship between the vaccine-induced Th1 response and protection against TB disease. For example, Kagina and coauthors evaluated BCG-specific CD4, CD8 lymphocytes and $\gamma \delta$ T-cells producing IFN $\gamma$, TNF $\alpha$, IL2 and IL17 in children who received the BCG vaccine at birth [59]. 
Two year follow-up allowed identifying a group of children for whom the protection was ineffective, i.e. TB developed in them and a group of children whose protection was effective, i.e. the disease did not develop in them in spite of their contacts with TB patients. The percentages and the cytokine profile of Mtb-specific $T$ lymphocytes in these groups did not differ significantly, so the authors deduced that the IFN $\gamma$-producing lymphocytes induced by BCG vaccination cannot signal of the vaccine effectiveness [59].

\section{CONCLUSIONS}

The data available suggest that the levels of Th1/IFNy responses reflect the activity of $\mathrm{TB}$ infection rather than a degree of protection. This in turn means that Th1 response is not a reliable correlate of protection, nor does it allow evaluating (even preliminary) the potential effectiveness of new candidate vaccines. Unfortunately, the current practice is often the contrary: Th1 response is taken as the main (and often the only) indicator of the immunogenicity and the potential efficacy of new candidate TB vaccines. The search for new markers of protection goes on. Some studies have already shown the dependence of vaccine-induced protection on Th17 lymphocytes [60-63]; several clinical research suggested population of the so-called nonclassical Th1 lymphocytes as a new protection correlate [64-66]. Validation of these data and the search for other reliable protection markers are important for further development and testing of TB vaccines.

\section{References}

1. Nechaeva O. B. Jepidemicheskaja situacija po tuberkulezu Rossii v 2016 godu. Otchet. M.: Federal'nyj Centr monitoringa protivodejstvija rasprostraneniju tuberkuleza. 2017. $69 \mathrm{~s}$.

2. Flynn JL, Chan J. Immunology of tuberculosis. Ann Rev Immunol. 2001; 19: 93-129

3. North RJ, Jung YJ. Immunity to tuberculosis. Annu Rev Immunol. 2004; 22: 599-623.

4. Kaufmann $\mathrm{SH}$, Tuberculosis: back on the immunologists' agenda. Immunity. 2006; 24 (4): 351-7.

5. Cooper AM, Khader SA. The role of cytokines in the initiation, expansion, and control of cellular immunity to tuberculosis. Immunol. Rev. 2008; 226: 191-204.

6. Lyadova IV. Inflammation and Immunopathogenesis of Tuberculosis Progression. In: Pere-Joan Cardona, editor. Understanding Tuberculosis - Analyzing the Origin of Mycobacterium Tuberculosis Pathogenicity. InTech; 2012: 19-42. Available from: http://www. intechopen.com/books/understanding-tuberculosis-analyzingthe-origin-of-mycobacterium-tuberculosis-pathogenicity.

7. Lyadova IV, Panteleev AV. Th1 and Th17 Cells in Tuberculosis: Protection, Pathology, and Biomarkers. Mediators Inflamm. 2015 ID 854507.

8. Gallant JE, Ko AH, Joel E. Cavitary pulmonary lesions in patients infected with human immunodeficiency virus. Clin Infect Dis. 1996; 22: 671-82.

9. Müller I, Cobbold SP, Waldmann H, Kaufmann SH. Impaired resistance to Mycobacterium tuberculosis infection after selective in vivo depletion of L3T4+ and Lyt-2+ T cells. Infect Immun. 1987; 55 (9): 2037-41.

10. Saunders BM, Cheers C. Inflammatory response following intranasal infection with Mycobacterium avium complex: role of T-cell subsets and gamma interferon. Infect Immun. 1995; 63 (6) 2282-87.

11. Ladel $\mathrm{CH}$, Daugelat $\mathrm{S}$, Kaufmann $\mathrm{SH}$. Immune response to Mycobacterium bovis bacille Calmette Guérin infection in majo histocompatibility complex class I- and II-deficient knock-out mice: contribution of CD4 and CD8 T cells to acquired resistance. Eur J Immunol. 1995; 25 (2): 377-84.

12. Flory CM, Hubbard RD, Collins FM. Effects of in vivo T lymphocyte subset depletion on mycobacterial infections in mice. J Leukoc Biol. 1992; 51 (3): 225-9.

13. Cooper AM, Dalton DK, Stewart TA, Griffin JP, Russell DG, Orme IM. Disseminated tuberculosis in interferon gamma genedisrupted mice. J Exp Med. 1993; 178 (6): 2243-47.

14. Flynn JL. An essential role for interferon gamma in resistance to Mycobacterium tuberculosis infection. J Exp Med. 1993; 178 (6): 2249-54.

15. Kamijo R, Le J, Shapiro D, Havell EA, Huang S, Aguet M, et al. Mice that lack the interferon-gamma receptor have profoundly altered responses to infection with Bacillus Calmette-Guérin and subsequent challenge with lipopolysaccharide. J Exp Med. 1993; 178 (4): 1435-40.

16. Flynn JL, Goldstein MM, Chan J, Triebold KJ, Pfeffer K,

Lowenstein CJ, et al. Tumor necrosis factor-alpha is required in the protective immune response against Mycobacterium tuberculosis in mice. Immunity. 1995; 2 (6): 561-72.

17. MacMicking JD, North RJ, LaCourse R, Mudgett JS, Shah SK, Nathan CF. Identification of nitric oxide synthase as a protective locus against tuberculosis. Proc Natl Acad Sci USA. 1997; 94 (10): 5243-8.

18. Cooper AM, Segal BH, Frank AA, Holland SM, Orme IM. Transient loss of resistance to pulmonary tuberculosis in p47(phox-/-) mice. Infect Immun. 2000; 68 (3): 1231-4.

19. Jung Y-J, LaCourse R, Ryan L, North RJ. Virulent but not avirulent Mycobacterium tuberculosis can evade the growth inhibitory action of a T helper 1-dependent, nitric oxide Synthase 2-independent defense in mice. J Exp Med. 2002; 196 (7): 991-8.

20. Scanga CA, Mohan VP, Tanaka K, Alland D, Flynn JL, Chan J. The inducible nitric oxide synthase locus confers protection against aerogenic challenge of both clinical and laboratory strains of Mycobacterium tuberculosis in mice. Infect Immun. 2001; 69 (12): $7711-7$

21. de Jong R, Altare F, Haagen IA, Elferink DG, Boer T, van Breda Vriesman PJ, et al. Severe mycobacterial and Salmonella infections in interleukin-12 receptor-deficient patients. Science. 1998; 280 (5368): 1435-8.

22. Jouanguy E, Lamhamedi-Cherradi S, Lammas D, Dorman SE, Fondanèche MC, Dupuis S, et al. A human IFNGR1 small deletion hotspot associated with dominant susceptibility to mycobacterial infection. Nat Genet. 1999; 21 (4): 370-8.

23. Dorman SE, Holland SM. Interferon-gamma and interleukin-12 pathway defects and human disease. Cytokine Growth Factor Rev. 2000; 11 (4): 321-33.

24. Newport $M$. The genetics of nontuberculous mycobacteria infection. Expert Rev Mol Med. 2003; 5 (6): 1-13.

25. Hambleton S, Salem S, Bustamante J, Bigley V, Boisson-Dupuis S, Azevedo J, et al. IRF8 Mutations and Human Dendritic-Cell Immunodeficiency. N Engl J Med. 2011; 365 (2): 127-38.

26. Lee WI, Huang JL, Yeh KW, Jaing TH, Lin TY, Huang YC, et al. Immune defects in active mycobacterial diseases in patients with primary immunodeficiency diseases (PIDs). J Formos Med Assoc. 2011; 110 (12): 750-8.

27. Bogunovic D, Byun M, Durfee LA, Abhyankar A, Sanal O, Mansouri D, et al. Mycobacterial disease and impaired IFNy immunity in humans with inherited ISG15 deficiency. Science. 2012; 337 (6102): 1684-8.

28. Khan TA, Schimke LF, Amaral EP, Ishfaq M, Barbosa Bonfim CC, Rahman $\mathrm{H}$, et al. Interferon-gamma reduces the proliferation of $M$. tuberculosis within macrophages from a patient with a novel hypomorphic NEMO mutation. Pediatr Blood Cancer. 2016; 63 (10): 1863-6.

29. Bustamante J, Boisson-Dupuis S, Abel L, Casanova J-L. Mendelian susceptibility to mycobacterial disease: Genetic, immunological, and clinical features of inborn errors of IFNy immunity. Semin Immunol. 2014; 26 (6): 454-70. 
30. Harris J, Keane J. How tumour necrosis factor blockers interfere with tuberculosis immunity. Clin Exp Immunol. 2010; 161(1): 1-9.

31. Salgado E, Gómez-Reino JJ. The risk of tuberculosis in patients treated with TNF antagonists. Expert Rev Clin Immunol. 2011; 7 (3): 329-40

32. Rose RM, Fuglestad JM, Remington L. Growth Inhibition of Mycobacterium avium Complex in Human Alveolar Macrophages by the Combination of Recombinant Macrophage Colonystimulating Factor and Interferon-gamma. Am J Respir Cell Mol Biol. 1991; 4 (3): 248-54.

33. Byrd TF. Multinucleated giant cell formation induced by IFN-gamma/lL-3 is associated with restriction of virulent Mycobacterium tuberculosis cell to cell invasion in human monocyte monolayers. Cell Immunol. 1998; 188 (2): 89-96.

34. Schaible UE, Sturgill-Koszycki S, Schlesinger PH, Russell DG. Cytokine activation leads to acidification and increases maturation of Mycobacterium avium-containing phagosomes in murine macrophages. J Immunol. 1998; 160 (3): 1290-6.

35. Flesch IE, Kaufmann SH. Attempts to characterize the mechanisms involved in mycobacterial growth inhibition by gamma-interferonactivated bone marrow macrophages. Infect. Immun. 1988; 56 (6): 1464-9.

36. Chan J, Xing Y, Magliozzo RS, Bloom BR. Killing of virulent Mycobacterium tuberculosis by reactive nitrogen intermediates produced by activated murine macrophages. J. Exp. Med. 1992. 175 (4): 1111-22.

37. Yu K, Mitchell C, Xing Y, Magliozzo RS, Bloom BR, Chan J. Toxicity of nitrogen oxides and related oxidants on mycobacteria: M. tuberculosis is resistant to peroxynitrite anion. Tuber Lung Dis. 1999; 79 (4): 191-8.

38. Majlessi L, Simsova M, Jarvis Z, Brodin P, Rojas M-J, Bauche C, et al. An increase in antimycobacterial Th1-cell responses by primeboost protocols of immunization does not enhance protection against tuberculosis. Infect Immun. 2006; 74 (4): 2128-37.

39. Mittrücker H-W, Steinhoff $U$, Köhler A, Krause M, Lazar D, Mex P, et al. Poor correlation between BCG vaccination-induced $T$ cell responses and protection against tuberculosis. Proc Natl Acad Sci USA. 2007; 104 (30): 12434-9.

40. Cowley C, Elkins KL. CD4+ T cells mediate IFNy-independent control of Mycobacterium tuberculosis infection both in vitro and in vivo. J Immunol. 2003; 171 (9): 4689-99.

41. Gallegos AM, van Heijst JW, Samstein M, et al., A gamma interferon independent mechanism of CD4 T cell mediated control of M. tuberculosis infection in vivo. PLoS Pathog, 2011; 7 (5): e1002052.

42. Nandi B, Behar SM. Regulation of neutrophils by interferon- $\gamma$ limits lung inflammation during tuberculosis infection. J Exp Med. 2011; 208 (11): 2251-62.

43. Barber DL, Mayer-Barber KD, Feng CG, Sharpe AH, Sher A. CD4 $T$ Cells Promote Rather than Control Tuberculosis in the Absence of PD-1-Mediated Inhibition. J Immunol. 2011; 186 (3): 1598-607.

44. Sakai S, Kauffman KD, Sallin MA, Sharpe AH, Young HA, Ganusov W, et al. CD4 T Cell-Derived IFNy Plays a Minimal Role in Control of Pulmonary Mycobacterium tuberculosis Infection and Must Be Actively Repressed by PD-1 to Prevent Lethal Disease. PLoS Pathog. 2016; 12 (5): e1005667.

45. Rook GA, Steele J, Ainsworth M, Champion BR. Activation of macrophages to inhibit proliferation of Mycobacterium tuberculosis: comparison of the effects of recombinant gamma-interferon on human monocytes and murine peritoneal macrophages. Immunology. 1986; 59 (3): 333-8.

46. Bermudez LE. Differential mechanisms of intracellular killing of Mycobacterium avium and Listeria monocytogenes by activated human and murine macrophages. The role of nitric oxide. Clin Exp Immunol. 1993; 91 (2): 277-81.

47. Meyer CG, Intemann CD, Förster B, Owusu-Dabo E, Franke A, Horstmann RD, Thye $\mathrm{T}$. No significant impact of IFNy pathway gene variants on tuberculosis susceptibility in a West African population. Eur J Hum Genet. 2016; 24 (5): 748-55.

48. Sahiratmadja E, Alisjahbana B, de Boer T, Adnan I, Maya A, Danusantoso $\mathrm{H}$, et al. Dynamic changes in pro- and antiinflammatory cytokine profiles and gamma interferon receptor signaling integrity correlate with tuberculosis disease activity and response to curative treatment. Infect Immun. 2007; 75 (2): 820-9. 49. Hirsch CS, Toossi Z, Othieno C, Johnson JL, Schwander SK, Robertson S, et al. Depressed T-Cell Interferon- $\gamma$ Responses in Pulmonary Tuberculosis: Analysis of Underlying Mechanisms and Modulation with Therapy. J Infect Dis. 1999; 180 (6): 2069-73.

50. Hasan Z, Jamil B, Ashraf M, Islam M, Dojki M, Irfan M, et al. Differential live Mycobacterium tuberculosis-, M. bovis BCG-, recombinant ESAT6-, and culture filtrate protein 10-induced immunity in tuberculosis. Clin Vaccine Immunol. 2009; 16 (7): 991-8.

51. Martinez V, Carcelain G, Badell E, Jouan M, Mauger I, Sellier P, et al. T-cell and serological responses to Erp, an exported Mycobacterium tuberculosis protein, in tuberculosis patients and healthy individuals. BMC Infect Dis. 2007; 7: 83.

52. Rueda CM, Marín ND, García LF, Rojas M. Characterization of CD4 and CD8 T cells producing IFNy in human latent and active tuberculosis. Tuberculosis (Edinb). 2010; 90 (6): 346-53.

53. Morosini M, Meloni F, Marone Bianco A, Paschetto E, Uccelli M, Pozzi E, et al. The assessment of IFN-gamma and its regulatory cytokines in the plasma and bronchoalveolar lavage fluid of patients with active pulmonary tuberculosis. Int $\mathrm{J}$ Tuberc Lung Dis. 2003; 7 (10): 994-1000.

54. Verbon A, Juffermans N, Van Deventer SJH, Speelman P, Van Deutekom H, Van Der Poll T. Serum concentrations of cytokines in patients with active tuberculosis (TB) and after treatment. Clin Exp Immunol. 1999; 115 (1): 110-3.

55. Sahiratmadja E, Alisjahbana B, Buccheri S, Di Liberto D, de Boer T, Adnan I, et al. Plasma granulysin levels and cellular interferon-gamma production correlate with curative host responses in tuberculosis, while plasma interferon-gamma levels correlate with tuberculosis disease activity in adults. Tuberculosis (Edinb). 2007; 87 (4): 312-21.

56. Nikitina IY, Panteleev A V., Sosunova E V., Karpina NL, Bagdasarian TR, Burmistrova IA, et al. Antigen-Specific IFNY Responses Correlate with the Activity of M. tuberculosis Infection but Are Not Associated with the Severity of Tuberculosis Disease. J Immunol Res. 2016; 2016 (Recent Advances in the Host Immunity to Mycobacterium tuberculosis Infection): 1-9.

57. Panteleev AV, Nikitina IY, Burmistrova IA, Kosmiadi GA, Radaeva TV, Amansahedov RB, et al. Severe Tuberculosis in Humans Correlates Best with Neutrophil Abundance and Lymphocyte Deficiency and Does Not Correlate with Antigen-Specific CD4 T-Cell Response. Front Immunol. 2017; 8: 1-16.

58. Tan $Q$, Xie WP, Min R, Dai GQ, Xu CC, Pan $H Q$, et al. Characterization of Th1- and Th2-type immune response in human multidrug-resistant tuberculosis. Eur J Clin Microbiol Infect Dis. 2012; 31 (6): 1233-42.

59. Kagina BMN, Abel B, Scriba TJ, Hughes EJ, Keyser A, Soares A, et al. Specific $T$ cell frequency and cytokine expression profile do not correlate with protection against tuberculosis after bacillus Calmette-Guérin vaccination of newborns. Am J Respir Crit Care Med. 2010; 182 (8): 1073-9

60. Umemura M, Yahagi A, Hamada S, Begum MD, Watanabe $H$, Kawakami K, et al. IL-17-mediated regulation of innate and acquired immune response against pulmonary Mycobacterium bovis bacille Calmette-Guerin infection. J Immunol. 2007; 178 (6): 3786-96.

61. Gopal R, Lin Y, Obermajer N, Slight S, Nuthalapati N, Ahmed M, Kalinski P, Khader SA. IL-23-dependent IL-17 drives Th1-cell responses following Mycobacterium bovis BCG vaccination. Eur J Immunol. 2012; 42 (2): 364-73.

62. Khader SA, Bell GK, Pearl JE, Fountain JJ, Rangel-Moreno J, Cilley GE, Shen F, Eaton SM, Gaffen SL, Swain SL, Locksley RM, Haynes L, Randall TD, Cooper AM. IL-23 and IL-17 in the establishment of protective pulmonary CD4+ T cell responses after vaccination and during Mycobacterium tuberculosis challenge. Nat Immunol. 2007; 8 (4): 369-77.

63. Griffiths KL, Pathan AA, Minassian AM, Sander CR, Beveridge NER, Hill AVS, Fletcher HA, McShane H. Th1/Th17 Cell Induction and Corresponding Reduction in ATP Consumption following Vaccination with the Novel Mycobacterium tuberculosis Vaccine MVA85A. PLoS One. 2011; 6 (8): e23463.

64. Arlehamn CL, Seumois G, Gerasimova A, Huang C, Fu Z, Yue X, et al. Transcriptional profile of tuberculosis antigen-specific $T$ cells 
reveals novel multifunctional features. J Immunol. 2014; 193 (6): 2931-40.

65. Strickland N, Müller TL, Berkowitz N, Goliath R, Carrington MN Wilkinson RJ, et al. Characterization of Mycobacterium tuberculosisSpecific Cells Using MHC Class II Tetramers Reveals Phenotypic Differences Related to HIV Infection and Tuberculosis Disease. $J$ Immunol. 2017; 199 (7): 2440-50.

\section{Литература}

1. Нечаева О. Б. Эпидемическая ситуация по туберкулезу в России в 2016 году. Отчет. М.: Федеральный Центр мониторинга противодействия распространению туберкулеза. 2017. 69 c.

2. Flynn JL, Chan J. Immunology of tuberculosis. Ann Rev Immunol. 2001; 19: 93-129.

3. North RJ, Jung YJ. Immunity to tuberculosis. Annu Rev Immunol. 2004; 22: 599-623.

4. Kaufmann SH, Tuberculosis: back on the immunologists' agenda. Immunity. 2006; 24 (4): 351-7.

5. Cooper AM, Khader SA. The role of cytokines in the initiation, expansion, and control of cellular immunity to tuberculosis. Immunol. Rev. 2008; 226: 191-204.

6. Lyadova IV. Inflammation and Immunopathogenesis of Tuberculosis Progression. In: Pere-Joan Cardona, editor. Understanding Tuberculosis - Analyzing the Origin of Mycobacterium Tuberculosis Pathogenicity. InTech; 2012: 19-42. Available from: http://www.intechopen.com/books/understanding-tuberculosisanalyzing-the-origin-of-mycobacterium-tuberculosis-pathogenicity.

7. Lyadova IV, Panteleev AV. Th1 and Th17 Cells in Tuberculosis: Protection, Pathology, and Biomarkers. Mediators Inflamm. 2015; ID 854507.

8. Gallant JE, Ko AH, Joel E. Cavitary pulmonary lesions in patients infected with human immunodeficiency virus. Clin Infect Dis. 1996; 22: 671-82.

9. Müller I, Cobbold SP, Waldmann H, Kaufmann SH. Impaired resistance to Mycobacterium tuberculosis infection after selective in vivo depletion of L3T4+ and Lyt-2+ T cells. Infect Immun. 1987; 55 (9): 2037-41.

10. Saunders BM, Cheers C. Inflammatory response following intranasal infection with Mycobacterium avium complex: role of T-cell subsets and gamma interferon. Infect Immun. 1995; 63 (6): 2282-87.

11. Ladel $\mathrm{CH}$, Daugelat $\mathrm{S}$, Kaufmann $\mathrm{SH}$. Immune response to Mycobacterium bovis bacille Calmette Guérin infection in major histocompatibility complex class I- and II-deficient knock-out mice: contribution of CD4 and CD8 T cells to acquired resistance. Eur J Immunol. 1995; 25 (2): 377-84.

12. Flory $\mathrm{CM}$, Hubbard RD, Collins FM. Effects of in vivo T lymphocyte subset depletion on mycobacterial infections in mice. J Leukoc Biol. 1992; 51 (3): 225-9.

13. Cooper AM, Dalton DK, Stewart TA, Griffin JP, Russell DG, Orme IM. Disseminated tuberculosis in interferon gamma genedisrupted mice. J Exp Med. 1993; 178 (6): 2243-47.

14. Flynn JL. An essential role for interferon gamma in resistance to Mycobacterium tuberculosis infection. J Exp Med. 1993; 178 (6): 2249-54.

15. Kamijo R, Le J, Shapiro D, Havell EA, Huang S, Aguet M, et al. Mice that lack the interferon-gamma receptor have profoundly altered responses to infection with Bacillus Calmette-Guérin and subsequent challenge with lipopolysaccharide. J Exp Med. 1993; 178 (4): 1435-40.

16. Flynn JL, Goldstein MM, Chan J, Triebold KJ, Pfeffer $\mathrm{K}$, Lowenstein CJ, et al. Tumor necrosis factor-alpha is required in the protective immune response against Mycobacterium tuberculosis in mice. Immunity. 1995; 2 (6): 561-72.

17. MacMicking JD, North RJ, LaCourse R, Mudgett JS, Shah SK, Nathan CF. Identification of nitric oxide synthase as a protective locus against tuberculosis. Proc Natl Acad Sci USA. 1997; 94 (10): 5243-8

18. Cooper AM, Segal BH, Frank AA, Holland SM, Orme IM. Transient
66. Nikitina IY, Panteleev AV, Kosmiadi GA, Serdyuk YV, Nenasheva TA Nikolaev AA, et al. Th1, Th17, and Th1Th17 Lymphocytes during Tuberculosis: Th1 Lymphocytes Predominate and Appear as LowDifferentiated CXCR3 + CCR6 + Cells in the Blood and Highly Differentiated CXCR3 +/- CCR6 - Cells in the Lung. J Immunol. 2018; 200 (6): 2090-103.

loss of resistance to pulmonary tuberculosis in p47(phox-/-) mice. Infect Immun. 2000; 68 (3): 1231-4.

19. Jung Y-J, LaCourse R, Ryan L, North RJ. Virulent but not avirulent Mycobacterium tuberculosis can evade the growth inhibitory action of a T helper 1-dependent, nitric oxide Synthase 2-independent defense in mice. J Exp Med. 2002; 196 (7): 991-8.

20. Scanga CA, Mohan VP, Tanaka K, Alland D, Flynn JL, Chan J. The inducible nitric oxide synthase locus confers protection against aerogenic challenge of both clinical and laboratory strains of Mycobacterium tuberculosis in mice. Infect Immun. 2001; 69 (12): 7711-7.

21. de Jong R, Altare F, Haagen IA, Elferink DG, Boer T, van Breda Vriesman PJ, et al. Severe mycobacterial and Salmonella infections in interleukin-12 receptor-deficient patients. Science. 1998; 280 (5368): 1435-8.

22. Jouanguy E, Lamhamedi-Cherradi S, Lammas D, Dorman SE, Fondanèche $\mathrm{MC}$, Dupuis $\mathrm{S}$, et al. A human IFNGR1 small deletion hotspot associated with dominant susceptibility to mycobacterial infection. Nat Genet. 1999; 21 (4): 370-8.

23. Dorman SE, Holland SM. Interferon-gamma and interleukin-12 pathway defects and human disease. Cytokine Growth Factor Rev. 2000; 11 (4): 321-33.

24. Newport M. The genetics of nontuberculous mycobacterial infection. Expert Rev Mol Med. 2003; 5 (6): 1-13.

25. Hambleton S, Salem S, Bustamante J, Bigley V, Boisson-Dupuis S, Azevedo J, et al. IRF8 Mutations and Human Dendritic-Cell Immunodeficiency. N Engl J Med. 2011; 365 (2): 127-38.

26. Lee WI, Huang JL, Yeh KW, Jaing TH, Lin TY, Huang YC, et al. Immune defects in active mycobacterial diseases in patients with primary immunodeficiency diseases (PIDs). J Formos Med Assoc. 2011; 110 (12): 750-8.

27. Bogunovic D, Byun M, Durfee LA, Abhyankar A, Sanal O, Mansouri D, et al. Mycobacterial disease and impaired IFNy immunity in humans with inherited ISG15 deficiency. Science. 2012; 337 (6102): 1684-8

28. Khan TA, Schimke LF, Amaral EP, Ishfaq M, Barbosa Bonfim CC, Rahman $\mathrm{H}$, et al. Interferon-gamma reduces the proliferation of $M$. tuberculosis within macrophages from a patient with a novel hypomorphic NEMO mutation. Pediatr Blood Cancer. 2016; 63 (10): 1863-6.

29. Bustamante J, Boisson-Dupuis S, Abel L, Casanova J-L. Mendelian susceptibility to mycobacterial disease: Genetic, immunological, and clinical features of inborn errors of IFNY immunity. Semin Immunol. 2014; 26 (6): 454-70.

30. Harris J, Keane J. How tumour necrosis factor blockers interfere with tuberculosis immunity. Clin Exp Immunol. 2010; 161(1): 1-9.

31. Salgado E, Gómez-Reino JJ. The risk of tuberculosis in patients treated with TNF antagonists. Expert Rev Clin Immunol. 2011; 7 (3): $329-40$

32. Rose RM, Fuglestad JM, Remington L. Growth Inhibition of Mycobacterium avium Complex in Human Alveolar Macrophages by the Combination of Recombinant Macrophage Colonystimulating Factor and Interferon-gamma. Am J Respir Cell Mol Biol. 1991; 4 (3): 248-54.

33. Byrd TF. Multinucleated giant cell formation induced by IFN-gamma/IL-3 is associated with restriction of virulent Mycobacterium tuberculosis cell to cell invasion in human monocyte monolayers. Cell Immunol. 1998; 188 (2): 89-96.

34. Schaible UE, Sturgill-Koszycki S, Schlesinger PH, Russell DG. Cytokine activation leads to acidification and increases maturation of Mycobacterium avium-containing phagosomes in murine 
macrophages. J Immunol. 1998; 160 (3): 1290-6.

35. Flesch IE, Kaufmann SH. Attempts to characterize the mechanisms involved in mycobacterial growth inhibition by gamma-interferonactivated bone marrow macrophages. Infect. Immun. 1988; 56 (6): 1464-9.

36. Chan J, Xing Y, Magliozzo RS, Bloom BR. Killing of virulent Mycobacterium tuberculosis by reactive nitrogen intermediates produced by activated murine macrophages. J. Exp. Med. 1992. 175 (4): 1111-22.

37. Yu K, Mitchell C, Xing Y, Magliozzo RS, Bloom BR, Chan J. Toxicity of nitrogen oxides and related oxidants on mycobacteria: M. tuberculosis is resistant to peroxynitrite anion. Tuber Lung Dis. 1999; 79 (4): 191-8.

38. Majlessi L, Simsova M, Jarvis Z, Brodin P, Rojas M-J, Bauche C, et al. An increase in antimycobacterial Th1-cell responses by primeboost protocols of immunization does not enhance protection against tuberculosis. Infect Immun. 2006; 74 (4): 2128-37.

39. Mittrücker H-W, Steinhoff $U$, Köhler A, Krause M, Lazar D, Mex P, et al. Poor correlation between BCG vaccination-induced $T$ cell responses and protection against tuberculosis. Proc Natl Acad Sci USA. 2007; 104 (30): 12434-9.

40. Cowley C, Elkins KL. CD4+ T cells mediate -independent control of Mycobacterium tuberculosis infection both in vitro and in vivo. J Immunol. 2003; 171 (9): 4689-99.

41. Gallegos AM, van Heijst JW, Samstein M, et al., A gamma interferon independent mechanism of CD4 T cell mediated control of M. tuberculosis infection in vivo. PLoS Pathog, 2011; 7 (5): e1002052.

42. Nandi B, Behar SM. Regulation of neutrophils by interferon- $\gamma$ limits lung inflammation during tuberculosis infection. J Exp Med. 2011; 208 (11): 2251-62.

43. Barber DL, Mayer-Barber KD, Feng CG, Sharpe AH, Sher A. CD4 $T$ Cells Promote Rather than Control Tuberculosis in the Absence of PD-1-Mediated Inhibition. J Immunol. 2011; 186 (3): 1598-607.

44. Sakai S, Kauffman KD, Sallin MA, Sharpe AH, Young HA, Ganusov W, et al. CD4 T Cell-Derived Plays a Minimal Role in Control of Pulmonary Mycobacterium tuberculosis Infection and Must Be Actively Repressed by PD-1 to Prevent Lethal Disease. PLoS Pathog. 2016; 12 (5): e1005667.

45. Rook GA, Steele J, Ainsworth M, Champion BR. Activation of macrophages to inhibit proliferation of Mycobacterium tuberculosis: comparison of the effects of recombinant gamma-interferon on human monocytes and murine peritoneal macrophages. Immunology. 1986; 59 (3): 333-8.

46. Bermudez LE. Differential mechanisms of intracellular killing of Mycobacterium avium and Listeria monocytogenes by activated human and murine macrophages. The role of nitric oxide. Clin Exp Immunol. 1993; 91 (2): 277-81.

47. Meyer CG, Intemann CD, Förster B, Owusu-Dabo E, Franke A, Horstmann RD, Thye T. No significant impact of pathway gene variants on tuberculosis susceptibility in a West African population. Eur J Hum Genet. 2016; 24 (5): 748-55.

48. Sahiratmadja E, Alisjahbana B, de Boer T, Adnan I, Maya A, Danusantoso $\mathrm{H}$, et al. Dynamic changes in pro- and antiinflammatory cytokine profiles and gamma interferon receptor signaling integrity correlate with tuberculosis disease activity and response to curative treatment. Infect Immun. 2007; 75 (2): 820-9.

49. Hirsch CS, Toossi Z, Othieno C, Johnson JL, Schwander SK, Robertson S, et al. Depressed T-Cell Interferon- $\gamma$ Responses in Pulmonary Tuberculosis: Analysis of Underlying Mechanisms and Modulation with Therapy. J Infect Dis. 1999; 180 (6): 2069-73.

50. Hasan Z, Jamil B, Ashraf M, Islam M, Dojki M, Irfan M, et al. Differential live Mycobacterium tuberculosis-, M. bovis BCG-, recombinant ESAT6-, and culture filtrate protein 10-induced immunity in tuberculosis. Clin Vaccine Immunol. 2009; 16 (7): 991-8.

51. Martinez V, Carcelain G, Badell E, Jouan M, Mauger I, Sellier P, et al. T-cell and serological responses to Erp, an exported Mycobacterium tuberculosis protein, in tuberculosis patients and healthy individuals. BMC Infect Dis. 2007; 7: 83.

52. Rueda CM, Marín ND, García LF, Rojas M. Characterization of CD4 and CD8 T cells producing in human latent and active tuberculosis. Tuberculosis (Edinb). 2010; 90 (6): 346-53.

53. Morosini M, Meloni F, Marone Bianco A, Paschetto E, Uccelli M, Pozzi E, et al. The assessment of IFN-gamma and its regulatory cytokines in the plasma and bronchoalveolar lavage fluid of patients with active pulmonary tuberculosis. Int $J$ Tuberc Lung Dis. 2003; 7 (10): 994-1000.

54. Verbon A, Juffermans N, Van Deventer SJH, Speelman P, Van Deutekom H, Van Der Poll T. Serum concentrations of cytokines in patients with active tuberculosis (TB) and after treatment. Clin Exp Immunol. 1999; 115 (1): 110-3.

55. Sahiratmadja E, Alisjahbana B, Buccheri S, Di Liberto D, de Boer T, Adnan I, et al. Plasma granulysin levels and cellular interferongamma production correlate with curative host responses in tuberculosis, while plasma interferon-gamma levels correlate with tuberculosis disease activity in adults. Tuberculosis (Edinb). 2007; 87 (4): 312-21.

56. Nikitina IY, Panteleev A V., Sosunova E V., Karpina NL, Bagdasarian TR, Burmistrova IA, et al. Antigen-Specific Responses Correlate with the Activity of M. tuberculosis Infection but Are Not Associated with the Severity of Tuberculosis Disease. J Immunol Res. 2016; 2016 (Recent Advances in the Host Immunity to Mycobacterium tuberculosis Infection): 1-9.

57. Panteleev AV, Nikitina IY, Burmistrova IA, Kosmiadi GA, Radaeva TV, Amansahedov RB, et al. Severe Tuberculosis in Humans Correlates Best with Neutrophil Abundance and Lymphocyte Deficiency and Does Not Correlate with AntigenSpecific CD4 T-Cell Response. Front Immunol. 2017; 8: 1-16.

58. Tan $Q$, Xie WP, Min R, Dai GQ, Xu CC, Pan $H Q$, et al. Characterization of Th1- and Th2-type immune response in human multidrug-resistant tuberculosis. Eur J Clin Microbiol Infect Dis. 2012; 31 (6): 1233-42.

59. Kagina BMN, Abel B, Scriba TJ, Hughes EJ, Keyser A, Soares A, et al. Specific $T$ cell frequency and cytokine expression profile do not correlate with protection against tuberculosis after bacillus Calmette-Guérin vaccination of newborns. Am J Respir Crit Care Med. 2010; 182 (8): 1073-9.

60. Umemura M, Yahagi A, Hamada S, Begum MD, Watanabe H, Kawakami $\mathrm{K}$, et al. IL-17-mediated regulation of innate and acquired immune response against pulmonary Mycobacterium bovis bacille Calmette-Guerin infection. J Immunol. 2007; 178 (6): 3786-96.

61. Gopal R, Lin Y, Obermajer N, Slight S, Nuthalapati N, Ahmed M, Kalinski P, Khader SA. IL-23-dependent IL-17 drives Th1-cell responses following Mycobacterium bovis BCG vaccination. Eur J Immunol. 2012; 42 (2): 364-73.

62. Khader SA, Bell GK, Pearl JE, Fountain JJ, Rangel-Moreno J, Cilley GE, Shen F, Eaton SM, Gaffen SL, Swain SL, Locksley RM, Haynes L, Randall TD, Cooper AM. IL-23 and IL-17 in the establishment of protective pulmonary CD4+ $T$ cell responses after vaccination and during Mycobacterium tuberculosis challenge. Nat Immunol. 2007; 8 (4): 369-77.

63. Griffiths $\mathrm{KL}$, Pathan $\mathrm{AA}$, Minassian AM, Sander $\mathrm{CR}$, Beveridge NER, Hill AVS, Fletcher HA, McShane H. Th1/Th17 Cell Induction and Corresponding Reduction in ATP Consumption following Vaccination with the Novel Mycobacterium tuberculosis Vaccine MVA85A. PLoS One. 2011; 6 (8): e23463.

64. Arlehamn CL, Seumois G, Gerasimova A, Huang C, Fu Z, Yue X, et al. Transcriptional profile of tuberculosis antigen-specific $T$ cells reveals novel multifunctional features. J Immunol. 2014; 193 (6): 2931-40.

65. Strickland N, Müller TL, Berkowitz N, Goliath R, Carrington MN, Wilkinson RJ, et al. Characterization of Mycobacterium tuberculosis-Specific Cells Using MHC Class II Tetramers Reveals Phenotypic Differences Related to HIV Infection and Tuberculosis Disease. J Immunol. 2017; 199 (7): 2440-50.

66. Nikitina IY, Panteleev AV, Kosmiadi GA, Serdyuk YV, Nenasheva TA, Nikolaev AA, et al. Th1, Th17, and Th1Th17 Lymphocytes during Tuberculosis: Th1 Lymphocytes Predominate and Appear as Low-Differentiated CXCR3 + CCR6 + Cells in the Blood and Highly Differentiated CXCR3 +/- CCR6 - Cells in the Lung. J Immunol. 2018; 200 (6): 2090-103. 